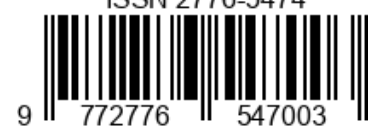

\title{
GAMBARAN PERGERAKAN INDEKS SEKTORAL DAN IHSG DI BURSA EFEK INDONESIA PADA MASA PANDEMI COVID-19 (Periode Februari 2020-Februari 2021)
}

\author{
Santy Sitohang \\ santysitohang90@gmail.com1
}

\begin{abstract}
Abstrak: Penyebaran Covid-19 merupakan sumber ketidakpastian bagi pelaku pasar yang mendorong terjadinya aksi gelombang jual saham di pasar bursa. Kepanikan pelaku pasar yang berlebihan menyebabkan laju Indeks Harga Saham Gabungan dan seluruh Indeks Sektoral di Bursa Efek Indonesia masuk zona merah dan mengalami penurunan lebih dari 5 persen. Penelitian ini dimaksudkan untuk mengetahui dan menganalisis bagaimana pergerakan Indeks Sektoral dan Indeks Harga Saham Gabungan di Bursa Efek Indonesia ditengah pandemi Covid19. Jenis penelitian ini menggunakan pendekatan deskriptif analisis. Objek penelitian difokuskan hanya membahas pergerakan IHSG dan seluruh indeks sektoral di masa pandemi Covid-19 selama 12 bulan perdagangan. Sumber data diambil dari situs www.yahoo.finance.com dari bulan Februari 2020-Februari 2021. Hasil penelitian menyimpulkan bahwa : (1) Pada awal pandemi Covid-19 masuk ke Indonesia seluruh indeks sektoral di Bursa Efek Indonesia melemah dan berada di zona merah. Dari 10 indeks sektoral di BEI menunjukkan dampak yang berbeda saat melewati masa pandemi Covid-19 dalam 12 bulan perdagangan. Terdapat 8 sektor di BEI kurang terdampak dan 2 sektor sangat terdampak oleh pandemi Covid-19. (2) Terdapat 2 sektor di Bursa Efek Indonesia yang pergerakan sahamnya sedang naik atau tahan banting saat menghadapi pandemi Covid-19 yaitu Sektor Pertanian dan Sektor Perdagangan dan Jasa. (3) Sebanyak 6 sektor di Bursa Efek Indonesia yang pergerakan sahamnya stabil atau kurang terdampak saat menghadapi pandemi Covid-19 yaitu Sektor Pertambangan, Sektor Industri Dasar, Sektor Aneka Industri, Sektor Infrastruktur, Sektor Keuangan dan Sektor Manufaktur. (4) Terdapat 2 sektor di Bursa Efek Indonesia yang pergerakan sahamnya sedang turun atau sangat terdampak saat menghadapi pandemi Covid-19 yaitu Sektor Barang Konsumsi dan Sektor Properti. (5) Laju Indeks Harga Saham Gabungan berfluktuasi saat menghadapi pandemi Covid-19. Pada Maret 2020, laju IHSG mengalami penurunan dan masuk zona merah. Dari bulan April-Agustus 2020 laju IHSG mulai menguat secara perlahan dan berada di zona hijau. Pada perdagangan September 2020, laju IHSG kembali anjlok karena penerapan kebijakan PSBB fase ke dua. Dari Oktober 2020-Februari 2021, laju IHSG terus menguat dan perkasa pada Februari 2021.
\end{abstract}

Kata Kunci : Pandemi Covid-19, Indeks Sektoral, IHSG, BEI 


\section{Pendahuluan}

Pada bulan Januari-Februari 2020, sebelum virus Covid-19 memasuki Indonesia, ternyata hampir semua sektor mengalami tren penurunan karena kondisi perekonomian global yang tidak stabil seperti persoalan perang dagang, masalah geopolitik di Timur Tengah dan fluktuasi harga komoditas. Sebagaimana diketahui bahwa musuh utama dari investor adalah ketidakpastian yang dapat mendorong pelaku pasar melakukan panic selling. Memasuki awal Maret 2020 wabah virus Covid-19 menjadi sumber ketidakpastian baru bagi pelaku pasar saham domestik. Kemunculan virus Covid-19 di Indonesia pada Maret 2020 langsung berdampak besar terhadap kondisi pasar saham domestik. Indeks Harga Saham Gabungan merosot tajam hingga menyentuh level 3.937,63 pada tanggal 24 Maret 2020 (www.finance.detik.com tanggal 10/04/2020). Seluruh indeks sektoral membukukan kinerja negatif, yang dipimpin sektor aneka indusrti $(-19,34$ persen), sektor keuangan (-18,58 persen) dan sektor infrastruktur (-14,76 persen) (www.market.bisnis.com tanggal 23 Maret 2020). Sentimen penurunan IHSG dan indeks sektoral disebabkan kepanikan ivestor atas penyebaran Covid-19 yang begitu cepat di berbagai kota di Indonesia. Rasa kekhawatiran investor semakin bertambah setelah World Health Organization (WHO) menetapkan virus Covid19 sebagai pandemi global. Pelaku pasar merespons berbagai berita negatif seputar virus corona seperti jumlah pasien yang terpapar, pasien yang meninggal dan yang sembuh. Pasar saham juga menunggu langkah yang diambil pemerintah untuk melawan penyebaran virus ini. Seiring bertambahnya jumlah penderita Covid-19 di Indonesia dan penerapan kebijakan Pembatasan Sosial Berskala Besar (PSBB) membuat semua sektor di BEI dan IHSG terus merosot dengan penurunan yang cukup tajam. Sepanjang Maret 2020 regulator pasar modal memberlakukan 6 kali trading halt (penghentian sementara perdagangan) karena laju IHSG mengalami pelemahan yang sangat tajam yaitu lebih dari $5 \%$. Kebijakan lainnya juga dilakukan untuk menahan kepanikan pelaku pasar diantaranya relaksasi buyback tanpa RUPS (www.finance.detik.com tanggal 10/04/2020).

Dari uraian latar belakang tersebut maka tujuan dari penelitian ini dilakukan adalah :

1. Untuk mengetahui dan menganalisis gambaran pergerakan Indeks Sektoral di Bursa Efek Indonesia pada masa pandemi Covid-19.

2. Untuk mengetahui sektor manakah di Bursa Efek Indonesia yang pergerakan sahamnya sedang naik di masa pandemi Covid-19.

3. Untuk mengetahui sektor manakah di Bursa Efek Indonesia yang pergerakan sahamnya cukup stabil di masa pandemi Covid-19.

4. Untuk mengetahui sektor manakah di Bursa Efek Indonesia yang pergerakan sahamnya sedang turun di masa pandemi Covid-19.

5. Untuk mengetahui dan menganalisis gambaran pergerakan Indeks Harga Saham Gabungan di Bursa Efek Indonesia pada masa pandemi Covid-19. 


\section{Tinjauan Pustaka}

\subsection{Pandemi Covid-19}

World Health Organization (WHO) secara resmi menetapkan status Covid-19 sebagai pandemi global pada tanggal 11 Maret 2020 (www.kompas.com tanggal 12/03/2020). Pandemi Covid-19 akan menjadi krisis yang menyentuh berbagai sektor mulai dari kesehatan, pendidikan, parawisata, sosial dan ekonomi. Rilis WHO yang menetapkan virus Covid-19 sebagai pandemi menjadi penekan utama bagi bursa saham global. Untuk menekan penyebaran Covid-19 berbagai negara memberlakukan kebijakan karantina wilayah (lockdown) yang menyebabkan aktivitas perekonomian global melambat signifikan. Perlambatan perekonomian global ini akan menimbulkan terjadinya resesi di beberapa negara. Lembaga pemeringkat Internasional, Moody's Investor Services memperkirakan, PDB riil sepanjang tahun 2020 dari Negara G-20 secara rata-rata akan minus 0,5 persen dengan estimasi pertumbuhan 2,6 persen (www.bareksa.com tanggal 30/03/2020). Sejak virus Covid-19 masuk di Indonesia pada awal Maret 2020 menimbulkan kepanikan bagi pelaku pasar modal sehingga melakukan aksi jual di pasar saham domestik. Ketidakpastian yang tinggi dan panik jual menyebabkan Indeks Harga Saham Gabungan mengalami tekanan hebat dan jatuh di titik terendahnya pada 24 Maret 2020 yang menyentuh 3.937,63 (www.bisnis.tempo.co tangga 24/03/2020).

\subsection{Indeks Sektoral}

Indeks harga saham adalah suatu indikator yang menunjukkan pergerakan harga saham dalam suatu periode. Pergerakan indeks menggambarkan kondisi pasar apakah sedang aktif atau lesu pada suatu periode tertentu. Indeks memberikan trend pergerakan saham saat ini apakah sedang naik, stabil atau turun. Jakarta Stock Industrial Classification (JASICA) mengkategorikan perusahaan di Bursa Efek Indonesia dalam 10 indeks sektoral yaitu (www.sahamok.net)

1. Sektor Pertanian (AGRI)

2. Sektor Pertambangan (MING)

3. Sektor Industri Dasar (BIND)

4. Sektor Aneka Industri (MISC)

5. Sektor Barang Konsumsi (CONS)

6. Sektor Properti, Konstruksi dan Real Estate (PROP)

7. Sektor Infrastuktur, Utilitas dan Transportasi (INFA)

8. Sektor Keuangan (FINA)

9. Sektor Perdangangan dan Jasa (TRAD)

10. Sektor Manufaktur.(MNFG) 


\subsection{Indeks Harga Saham Gabungan}

Indeks Harga Saham Gabungan adalah indeks yang mengukur kinerja seluruh saham yang tercatat di papan utama dan papan pengembangan Bursa Efek Inodensia. IHSG menjadi acuan bagi para investor dalam menentukan kapan membeli atau menjual investasinya di pasar modal. Pergerakan IHSG ini menjadi gambaran seluruh saham yang ada terdaftar di BEI. Pada saat IHSG sedang meningkat itu menunjukkan bahwa rata-rata saham yang melantai di BEI sedang mengalami kenaikan, sebaliknya jika IHSG sedang menurun maka dapat disimpulkan rata-rata saham di BEI sedang mengalami penurunan. IHSG merupakan indeks yang mencerminkan pergerakan harag saham yang ada di Bursa Efek Indonesia. Menurut BEI (2020) tujuan dan manfaat indeks saham adalah :

1. Mengukur sentimen pasar

2. Dijadikan produk investasi pasif

3. Sebagai tolok ukur (bencmark) kinerja suatu portofolio

4. Proksi dalam mengukur dan membuat model pengembalian investasi, risiko sistematis, dan kinerja yang disesuaikan dengan risiko

5. Proksi untuk kelas aset pada alokasi aset

\section{Metode Penelitian}

Penelitian ini dilakukan dengan menggunakan pendekatan deskriptif. Penelitian deskriptif bertujuan untuk memberikan gambaran atau deskripsi tentang suatu keadaan secara objektif untuk memecahkan masalah atau menjawab permasalah yang sedang dihadapi pada situasi sekarang. Objek dari penelitian ini adalah Indeks Harga Saham Gabungan dan 10 Indeks Sektoral di Bursa Efek Indonesia yang terdiri dari sektor pertanian, sektor pertambangan, sektor industri dasar, sektor aneka industri, sektor barang konsumsi, sektor infrastruktur, sektor properti, sektor perdagangan dan jasa, sektor keuangan dan sektor manufaktur. Sumber data diambil dari www.yahoofinance.com secara bulanan dari periode Februari 2020-Februari 2021. 


\section{Hasil Dan Pembahasan}

\subsection{Pergerakan Indeks Sektoral}

Penularan Covid-19 di Indonesia telah memberikan dampak yang signifikan terhadap berbagai sektor di BEI dan salah satunya adalah indeks sektoral. Berikut pergerakan indeks sektoral di BEI secara bulanan dari Februari 2020-Februari 2021.

Tabel 4.1

Gambaran Pergerakan Indeks Sektoral di BEI

Periode Februari 2020 - Februari 2021

\begin{tabular}{|c|c|c|c|c|c|c|c|c|c|c|}
\hline Bulan & AGRI & MING & BIND & MISC & CONS & PROP & INFA & TRAD & FINA & MNFG \\
\hline Feb 20 & $1,156.74$ & $1,339.07$ & 758.76 & 989.39 & $1,742.94$ & 427.13 & 956.77 & 671.29 & $1,249.34$ & $1,195.13$ \\
\hline Mar 20 & 928.46 & $1,184.09$ & 580.26 & 733.03 & $1,659.14$ & 338.41 & 805.43 & 602.27 & 989.67 & $1,027.10$ \\
\hline Mar-Feb & -228.28 & -154.98 & -178.5 & -256.36 & -83.80 & -88.72 & -151.34 & -69.02 & -259.67 & -168.03 \\
\hline Apri 20 & 957.87 & $1,208.92$ & 761.66 & 733.54 & $1,821.39$ & 293.05 & 915.67 & 606.94 & 947.78 & $1,176.09$ \\
\hline Apr-Mar & 29.41 & 24.83 & 181.4 & 0.51 & 162.25 & -45.36 & 110.24 & 4.67 & -41.89 & 148.99 \\
\hline Mei 20 & 964.93 & $1,238.20$ & 745.73 & 858.4 & $1,806.73$ & 322.96 & 864.08 & 606.63 & 962.52 & $1,186.70$ \\
\hline Mei-Apr & 7.06 & 29.28 & -15.93 & 124.86 & -14.66 & 29.91 & -51.59 & -0.31 & 14.74 & 10.61 \\
\hline Juni 20 & $1,027.52$ & $1,238.20$ & 721.66 & 867.12 & $1,800.90$ & 322.04 & 883.18 & 606.14 & $1,059.59$ & $1,174.27$ \\
\hline Jun-Mei & 62.59 & -14.25 & -24.07 & 8.72 & -5.83 & -0.92 & 19.10 & -0.49 & 97.07 & -12.43 \\
\hline Juli 20 & $1,156.32$ & $1,223.95$ & 752.08 & 921.73 & $1,886.05$ & 300.50 & 904.06 & 622.99 & $1,134.93$ & $1,230.50$ \\
\hline Jul-Jun & 128.80 & 146.23 & 30.42 & 54.61 & 85.15 & -21.54 & 20.88 & 16.85 & 75.34 & 56.23 \\
\hline Agst 20 & $1,185.13$ & $1,398.81$ & 760.26 & 912.72 & $1,933.18$ & 297.39 & 856.87 & 628.75 & $1,185.07$ & $1,249.81$ \\
\hline Ags-Jul & 28.81 & 28.63 & 8.18 & -9.01 & 47.13 & -3.11 & -47.19 & 5.76 & 50.14 & 19.31 \\
\hline Sept 20 & $1,137.47$ & $1,332.02$ & 709.51 & 820.3 & $1,828.95$ & 340.62 & 785.95 & 631.21 & $1,039.76$ & $1,169.29$ \\
\hline Sep-Agst & -47.66 & -66.79 & -50.75 & -92.42 & -104.23 & 43.23 & -70.92 & 2.46 & -145.31 & -80.52 \\
\hline Okt 20 & $1,199.64$ & $1,418.02$ & 762.32 & 958.06 & $1,805.20$ & 330.97 & 808.58 & 642.88 & $1,139.65$ & $1,169.29$ \\
\hline Ok-Sep & 62.17 & 86.00 & 52.81 & 137.76 & -23.75 & -9.65 & 22.63 & 11.67 & 99.89 & 44.19 \\
\hline Nop 20 & $1,317.06$ & $1,674.09$ & 863.29 & 958.28 & $1,839.38$ & 372.4 & 945.01 & 681.11 & $1,259.17$ & $1,276.49$ \\
\hline Nop-Okt & 117.42 & 256.07 & 100.97 & 0.22 & 34.18 & 41.43 & 136.43 & 38.23 & 119.52 & 63.01 \\
\hline Des 20 & $1,497.95$ & $1,915.56$ & 920.97 & $1,081.05$ & $1,832.11$ & 396.89 & $1,001.02$ & 766.37 & $1,333.18$ & $1,326.18$ \\
\hline Des-Nop & 180.89 & 241.47 & 57.68 & 122.77 & -7.27 & 24.49 & 56.01 & 85.26 & 74.01 & 49.69 \\
\hline Jan 21 & $1,380.57$ & $1,893.30$ & 912.30 & $1,070.33$ & $1,696.90$ & 365.04 & 964.05 & 800.08 & $1,329.57$ & $1,271.17$ \\
\hline Jan-Des & -117.38 & -22.26 & -8.67 & -10.72 & -135.21 & -31.85 & -36.97 & 33.71 & -3.61 & -55.01 \\
\hline Feb 21 & $1,438.28$ & $2,048.92$ & 951.10 & 996.75 & $1,707.35$ & 377.96 & $1,070.39$ & 861.93 & $1,458.86$ & $1,280.42$ \\
\hline Feb-Jan & 57.71 & 155.62 & 38.8 & -73.58 & 10.45 & 12.92 & 106.34 & 61.85 & 129.29 & 9.25 \\
\hline
\end{tabular}

Sumber : www.yahoo.finance. (data diolah, 2021)

Berdasarkan data yang tertera pada tabel diatas maka pergerakan indeks sektoral di BEI secara bulanan (Februari 2020-Februari 2021) sebagai berikut :

1. Pada awal penyebaran Covid-19 masuk ke Indonesia semua indeks sektoral mengalami kemerosotan dan masuk zona merah. Ada tiga indeks sektoral yang terpeleset jauh yaitu sektor keuangan mengalami penurunan sebesar 259,67 poin di susul sektor aneka industri turun sebesar 256,36 dan sektor pertanian turun sebesar 228,28 poin. Pelaku pasar melakukan aksi jual saham.

2. Pada penutupan perdagangan bulan April 2020 sebanyak 8 indeks sektoral menguat dan masuk zona hijau dan 2 sektor melemah yaitu sektor properti dan 
sektor keuangan. Penguatan indeks sektoral dipimpin sektor industri dasar dan kimia menguat sebesar 181,4 poin dari bulan sebelumnya disusul sektor manufaktur yang naik sebesar 148,99 poin.

3. Pada perdagangan Mei 2020 terdapat sebanyak 6 sektor menguat yaitu sektor pertanian, sektor pertambangan, sektor aneka industri, sektor properti, sektor keuangan dan sektor manufaktur. Penguatan tertinggi dipimpin sektor aneka industri sebesar 124,86 poin. Di sisi lain sebanyak 4 sektor melemah yaitu sektor industri dasar, sektor barang konsumsi, sektor infrastruktur dan sektor perdagangan dan jasa. Pelemahan dipimpin oleh sektor infrastruktur sebesar 51,59 poin.

4. Untuk penutupan perdagangan Juni 2020 terdapat 4 indeks sektoral hijau yaitu sektor pertanian, sektor aneka industri, sektor infrastruktur dan sektor keuangan. Penguatan dipimpin oleh sektor keuangan naik sebesar 97,07 poin disusul sektor pertanian naik sebesar 62,59 poin. Di sisi lain terdapat 6 indeks sektoral merah yaitu sektor pertambangan, sektor industri dasar, sektor barang konsumsi, sektor properti, sektor perdagangan dan sektor manufaktur. Pelemahan dipimpin oleh sektor industri dasar kimia sebesar 24,07 poin.

5. Indeks sektoral untuk penutupan perdagangan Juli 2020 menunjukkan 9 sektor parkir di zona hijau dengan penguatan tertinggi diraih oleh sektor pertambangan sebesar 146,23 poin disusul sektor pertanian yang naik sebesar 128,80 poin. Satu-satunya sektor yang melemah dan masuk zona merah adalah sektor properti yang turun sebesar 21,54 poin.

6. Pada perdagangan bulan Agustus 2020 sebanyak 7 indeks sektor menghijau yaitu sektor pertanian, sektor pertambangan, sektor industri dasar, sektor barang konsumsi, sektor perdagangan, sektor keuangan dan sektor manufaktur. Penguatan dipimpin oleh sektor keuangan sebesar 50,14 poin. Sedangkan 3 sektor yang mengalami pelemahan adalah sektor aneka industri, sektor properti dan sektor infrastruktur. Pelemahan dipimpin oleh sektor infrastrukut sebesar 47,19 poin.

7. Pada penutupan perdagangan bulan September 2020 hanya dua sektor yang mampu menguat di BEI yaitu sektor properti naik sebesar 43,23 poin dan sektor perdagangan sebesar 2,46 poin. Sedangkan 8 indeks sektoral merah yaitu sektor pertanian, sektor pertambangan, sektor industri dasar, sektor aneka industri, sektor barang konsumsi, sektor infrastruktur, sektor keuangan dan sektor manufaktur. Pelemahan dipimpin oleh sektor barang konsumsi sebesar 104,23 poin.

8. Sepanjang bulan Oktober 2020 menunjukkan sebanyak 8 indeks sektoral mengalami penguatan yaitu sektor pertanian, sektor perdagangan, sektor industri dasar, sektor aneka industri, sektor infrastruktur, sektor perdagangan, sektor keuangan dan sektor manufaktur. Penguatan tertinggi diraih oleh sektor aneka industri dengan kenaikan sebesar 137,76 poin. Sedangkan dua sektor masuk zona merah yaitu sektor barang konsumsi dan sektor properti. 
9. Pada bulan Nopember 2020 semua indeks sektoral mengalami penguatan dan parkir di zona hijau. Indeks sektoral tertinggi diraih oleh sektor pertambangan dengan poin 256,07 selanjutnya disusul sektor keuangan dengan kenaikan sebesar 119,25 poin.

10. Untuk periode Desember 2020 sebanyak 9 indeks sektoral positif yaitu sektor pertanian, sektor pertambangan, sektor perdagangan, sektor industri dasar, sektor aneka industri, sektor properti, sektor infrastruktur, sektor keuangan dan sektor manufaktur. Indeks tertinggi dipimpin oleh sektor pertambangan dengan poin 241,47 . Sedangkan sektor barang konsumsi melemah dengan poin 7,27 .

11. Periode Januari 2021 sebanyak 9 sektor melemah yaitu sektor pertanian, sektor pertambangan, sektor industri dasar, sektor barang konsumsi, sektor aneka industri, sektor infrastruktur, sektor properti, sektor keuangan dan sektor manufaktur. Pelemahan dipimpin oleh sektor pertanian sebesar 117,38 sedangkan perdagangan dan jasa menguat sebesar 33,71.

12. Pada perdagangan Februari 2021 terdapat 9 indeks sektoral menguat positif yaitu sektor pertanian, sektor pertambangan, sektor industri dasar, sektor barang konsumsi, perdagangan, sektor infrastruktur, sektor properti, sektor keuangan dan sektor manufaktur. Indeks sektoral yang mengalami penguatan tertinggi adalah sektor pertambangan sebesar 155,62. Sektor yang mengalami pelemahan adalah sektor aneka industri sebesar 73,58 poin.

\subsection{Gambaran Perubahan Pergerakan Indeks Sektoral}

Untuk mengetahui bagaimana gambaran perubahan pergerakan indeks sektoral di BEI pada masa pandemi Covid-19 selama 12 bulan perdagangan dapat dilihat pada tabel berikut ini.

Tabel 4.2

Gambaran Perubahan Pergerakan Indeks Sektoral di BEI Periode Maret 2020-Februari 2021

\begin{tabular}{|l|r|r|r|r|r|r|r|r|r|r|}
\hline \multicolumn{1}{|c|}{ Bulan } & \multicolumn{1}{c|}{ AGRI } & \multicolumn{1}{c|}{ MING } & \multicolumn{1}{c|}{ BIND } & \multicolumn{1}{c|}{ MISC } & \multicolumn{1}{c|}{ CONS } & PROP & \multicolumn{1}{c|}{ INFA } & TRAD & \multicolumn{1}{c|}{ FINA } & MNFG \\
\hline Maret 20 & -228.28 & -154.98 & -178.5 & -256.36 & -83.8 & -88.72 & -151.3 & -69 & -259.7 & -168 \\
\hline April 20 & 29.41 & 24.83 & 181.4 & 0.51 & 162.25 & -45.36 & 110.24 & 4.67 & -41.89 & 148.99 \\
\hline Mei 20 & 7.06 & 29.28 & -15.93 & 124.86 & -14.66 & 29.91 & -51.59 & -0.31 & 14.74 & 10.61 \\
\hline Juni 20 & 62.59 & -14.25 & -24.07 & 8.72 & -5.83 & -0.92 & 19.10 & -0.49 & 97.07 & -12.43 \\
\hline Juli 20 & 128.80 & 146.23 & 30.42 & 54.61 & 85.15 & -21.54 & 20.88 & 16.85 & 75.34 & 56.23 \\
\hline Agustus 20 & 28.81 & 28.63 & 8.18 & -9.01 & 47.13 & -3.11 & -47.19 & 5.76 & 50.14 & 19.31 \\
\hline September 20 & -47.66 & -66.79 & -50.75 & -92.42 & -104.23 & 43.23 & -70.92 & 2.46 & -145.31 & -80.52 \\
\hline Oktober 20 & 62.17 & 86.00 & 52.81 & 137.76 & -23.75 & -9.65 & 22.63 & 11.67 & 99.89 & 44.19 \\
\hline Nopember 20 & 117.42 & 256.07 & 100.97 & 0.22 & 34.18 & 41.43 & 136.43 & 38.23 & 119.52 & 63.01 \\
\hline Desember 20 & 180.89 & 241.47 & 57.68 & 122.77 & -7.27 & 24.49 & 56.01 & 85.26 & 74.01 & 49.69 \\
\hline Januari 21 & -117.38 & -22.26 & -8.67 & -10.72 & -135.21 & -31.85 & -36.97 & 33.71 & -3.61 & -55.01 \\
\hline Februari 21 & 57.71 & 155.62 & 38.8 & -73.58 & 10.45 & 12.92 & 106.34 & 61.85 & 129.29 & 9.25 \\
\hline Zona merah & $\mathbf{3}$ & $\mathbf{4}$ & $\mathbf{5}$ & $\mathbf{5}$ & $\mathbf{7}$ & $\mathbf{7}$ & $\mathbf{5}$ & $\mathbf{3}$ & $\mathbf{4}$ & $\mathbf{4}$ \\
\hline Zona hijau & $\mathbf{9}$ & $\mathbf{8}$ & $\mathbf{7}$ & $\mathbf{7}$ & $\mathbf{5}$ & $\mathbf{5}$ & $\mathbf{7}$ & $\mathbf{9}$ & $\mathbf{8}$ & $\mathbf{8}$ \\
\hline
\end{tabular}

Sumber : www.yahoo.finance (data diolah, 2021) 
Berdasarkan data yang tertera pada tabel diatas maka dapat dilihat bagaimana gambaran perubahan pergerakan dari 10 indeks sektoral di BEI dalam menghadapi situasi pandemi Covid-19. Sebenarnya tidak semua sektor terdampak sama parahnya saat melewati pandemi virus Covid-19 melanda pasar modal. Dari data yang tersedia pada tabel 4.2 maka trend pergerakan saham dari setiap sektor dapat dikategorikan dalam 3 kondisi terutama saat menghadapai krisis pandemi Covid-19 ini yaitu :

1. Sektor yang pergerakan sahamnya naik saat pandemi

Dari tabel diatas menunjukkan terdapat 2 sektor yang mengalami pertumbuhan positif saat masa pandemi Covid-19 yaitu Sektor Pertanian (AGRI) dan Sektor Perdagangan dan Jasa (TRAD). Dari 12 bulan perdagangan, pergerakan saham dari kedua sektor tersebut mengalami penguatan dan hanya 3 kali masuk zona merah dan 9 kali bertengger di zona hijau. Pada bulan Maret 2020 sektor pertanian menjadi salah satu sektor yang paling terdampak parah karena harga CPO yang menjadi urat nadi sektor agrikultur sudah turun karena berkurangnya permintaan dari negara lain dan banyaknya pabrik tidak beroperasi akibat penutupan wilayah. Dari bulan April 2020-Februari 2021 sektor pertanian tumbuh positif dan menjadi primadona di masa pandemi Covid-19. Hal ini dikarenakan produk yang dihasilkan dari sektor pertanian sangat dibutuhkan masyarakat. Subsektor tanaman pangan menjadi penyumbang tertinggi di sektor pertanian. Sektor pertanian mampu mencetak kinerja yang bagus dan menjadi salah satu penopang perekonomian di masa pandemi Covid-19. Sektor perdagangan dan jasa mengalami tekanan yang cukup parah sejak mewabahnya Covid-19 di Indonesia. Dari bulan Maret-Juni 2020 laju pergerakan saham sektor mengalami pelemahan karena tingkat penjualan barang dan jasa menurun akibat penerapan kebijakan PSBB di beberapa wilayah. Keadaan mulai berbalik arah pada bulan Juli 2020 - Februari 2021 sektor perdagangan dan jasa terus menguat dan konsisten di zona hijau. Penguatan pergerakan saham sektor perdagangan dan jasa ditopang melalui konsumsi rumah tangga dan bisnis ritel yang terus mengalami peningkat. Bisnis ritel dan sektor konsumsi menjadi motor penggerak pemulihan ekonomi di masa pandemi Covid-19. Bisnis ritel menjadi bantalan bagi pasar modal domestik yang ditinggal oleh investor asing karena pandemi.

2. Sektor yang pergerakan sahamnya stabil saat pandemi

Selama 12 bulan perdagangan saat pandemi melanda pasar modal domestik terdapat 6 sektor yang dikategorikan kurang terdampak terhadap situasi pandemi yaitu Sektor Pertambangan (MING), Sektor Industri Dasar (BIND), Sektor Aneka Industri (MISC), Sektor Infrastruktur (INFA), Sektor Keuangan (FINA) dan Sektor Manufaktur (MNFG). Meskipun kinerja keenam sektor ini berfluktuasi pada masa pandemi Covid-19 ini namun relatif kurang berdampak dan cukup stabil sehingga pergerakan sahamnya banyak bertengger di zona hijau. Keenam sektor ini memang terdampak oleh situasi virus Covid-19 namun pengaruhnya tidak signifikan. Pada awal pandemi semua sektor ini anjlok karena kepanikan pelaku pasar menghadapi situasi Covdi-19 namun seiring berjalannya waktu ternyata laju perubahan indeks sektoral ini lebih dipengaruhi oleh faktor teknikal dan maraknya aksi profit taking di pasar bursa. 
3. Sektor yang pergerakan sahamnya turun saat pandemi

Sebanyak 2 sektor yang dinilai terdampak parah saat pandemi Covid-19 dan sering terpeleset di zona merah yaitu Sektor Barang Konsumsi (CONS) dan Sektor Properti (PROP). Dari 12 kali perdagangan ternyata kedua sektor ini 7 kali masuk zona merah dan 5 kali masuk zona hijau. Pada awal wabah virus corona masuk ke Indonesia memang sektor barang konsumsi berhasil menguat karena produknya dibutuhkan masyarakat sehingga dianggap mampu bertahan dan cukup kebal dalam menghadapi serangan Covid-19. Selain itu pasar swalayan dan pertokoan menjadi ujung tombak penjualan barang-barang konsumsi sehingga diijinkan beroperasi ketika kebijakan PSBB dijalankan. Seiring berjalannya waktu ternyata penerapan PSBB yang ketat dan Pemberlakukan Pembatasan Kegiatan Masyarakat (PPKM) telah menurunkan daya beli masyarakat. Rendahnya daya beli masyarakat berdampak secara signifkan terhadap pelemahan indek sektor barang konsumsi di BEI. Sementara sektor yang terdampak paling parah dari awal munculnya Covid-19 adalah sektor properti. Hal ini dikarenakan pusat perbelanjaan yang menjadi subsektor properti terdampak paling dalam selama masa pandemi Covid-19. Sebelum kebijakan PSBB diberlakukan ternyata jumlah pengunjung pusat perbelanjaan sudah turun karena banyak warga yang takut bepergian ke tempat umum yang ramai dikunjungin orang. Setelah kebijakan PSBB diberlakukan banyak pusat perbelanjaan tidak diijinkan untuk beroperasi. Penjualan produk properti seperti perumahan dan apartemen berkurang karena daya beli masyarakat turun sehingga indeks sektoral properti terdepresiasi paling parah.

\subsection{Pergerakan Indeks Harga Saham Gabungan}

Merebaknya Covid-19 di Indonesia telah menimbulkan kepanikan bagi investor yang memicu sentimen penurunan IHSG di pasar modal. Kondisi IHSG menjadi perhatian pelaku pasar modal setelah virus Covid-19 ditetapkan sebagai pandemi global. Berikut pergerakan IHSG di BEI selama 12 kali perdagangan.

Tabel 4.3

Pergerakan IHSG di BEI

\begin{tabular}{|l|r|r|}
\hline \multicolumn{1}{|c|}{ Bulan } & $\begin{array}{c}\text { Indeks } \\
\text { IHSG }\end{array}$ & $\begin{array}{c}\text { Perubahan } \\
\text { Indeks }\end{array}$ \\
\hline Februari 2020 & $5,452.70$ & \\
\hline Maret 2020 & $\mathbf{4 , 5 3 8 . 9 3}$ & $\mathbf{- 9 1 3 . 7 7}$ \\
\hline April 2020 & $4,716.40$ & 177.47 \\
\hline Mei 2020 & $4,753.61$ & 37.21 \\
\hline Juni 2020 & $4,905.39$ & 151.78 \\
\hline Juli 2020 & $5,149.63$ & 244.24 \\
\hline Agustus 2020 & $5,238.49$ & 88.86 \\
\hline September 2020 & $\mathbf{4 , 8 7 0 . 0 4}$ & $\mathbf{- 3 6 8 . 4 5}$ \\
\hline Oktober 2020 & $5,128.23$ & 258.19 \\
\hline Nopember 2020 & $5,612.42$ & 484.19 \\
\hline Desember 2020 & $5,979.07$ & 366.65 \\
\hline Januari 2021 & $5,862.35$ & -116.72 \\
\hline Februari 2021 & $\mathbf{6 , 2 4 1 . 8 0}$ & 379.45 \\
\hline
\end{tabular}

Sumber : www.yahoo.finance (data diolah, 2021) 
Dari tabel diatas dapat dilihat pergerakan Indeks Harga Saham Gabungan selama 12 bulan perdagangan. Untuk mengetahui seberapa besar dampak pandemi Covid-19 dapat mempengaruhi kondisi IHSG di pasar modal secara bulanan akan diuraikan sebagai berikut :

1. Sebelum pandemi Covid-19 terjadi di Indonesia ternyata kinerja IHSG pada bulan Februari 2021 di tutup pada level 5.452,70. Pada tanggal 2 Maret 2020, Presiden mengumumkan secara resmi bahwa dua warga negara Indonesia terifeksi virus Covid-19. Pengumuman kasus positif Covid-19 ini menimbulkan kepanikan di bursa saham sehingga pelaku pasar berbondongbondong melakukan aksi jual yang mengakibatkan laju IHSG anjlok. Pada tanggal 24 Maret 2020 IHSG terjun bebas ke titik terendah yaitu pada level 3.937. Sepanjang bulan Maret 2020 tim regulator BEI melakukan 6 kali penghentian perdagangan (trading halt) akibat IHSG anjlok sampai 5\% lebih yaitu pada 12 Maret 2020, 13 Maret 2020, 17 Maret 2020, 19 Maret 2020, 22 Maret 2020 dan 30 maret 2020. Pada Maret 2020 IHSG di tutup di level 4.538,93 dan mengalami penurunan sebesar 913,77 poin dari bulan sebelumnya. Selama bulan Maret 2020, Pegawas pasar modal telah mengeluarkan berbagai kebijakan untuk menjaga daya tahan dan mengendalikan votabilitas pasar modal. Melarang short selling, memberlakukan trading halt untuk penurunan 5 persen dan asymmetric autorejection, memendekkan jam perdagangan bursa, memperbolehkan buyback saham tanpa melalui RUPS.

2. Pergerakan IHSG bulan April 2020 di tutup menguat ke level 4.716,40 dengan kenaikan sebesar 177.47 poin dari bulan sebelumnya. Sepanjang April 2020 sebanyak 258 saham menguat, 136 terkoreksi dan 146 stagnan (www.Bisnis.com tanggal 30/04/2020). Salah satu faktor pendorong menguatnya IHSG yaitu uji tes obat Remdesivir yang mencatatkan hasil positif sehingga memberikan rasa optimisme bagi pelaku pasar yang beranggapan bahwa obat Covid-19 segera ditemukan dan ekonomi akan berangsur-angsur normal kembali. Pernyataan pemerintah yang menyatakan telah mendatangkan obat untuk menyembuhkan pasien yang terinfeksi Covid19 juga menjadi sentimen positif bagi pelaku pasar.

3. Pada bulan Mei 2020, pergerakan IHSG kembali menghijau pada level 4.753.61, penguatan IHSG sepanjang bulan Mei 2020 karena adanya respon positif dari pasar tentang adanya perkembangan penelitian vaksi Covid-19 dan pembatasan PSBB yang dilakukan di beberapa kota besar di Indonesia dianggap cukup berhasil menekan penyebaran virus corona.

4. Sepanjang bulan Juni 2020, kinerja IHSG mengalami penguatan dari bulan sebelumnya yaitu pada posisi 4.538,93 dengan poin 151,78. Pada awal Juni 2020 pemerintah menetapkan skenario kenormalan baru (new normal) dan melonggarkan PSBB. Beberapa restoran dan pusat perbelanjaan diperbolehkan beroperasi meskipun pengunjung dibatasi $50 \%$ dari kapasitas. Penguatan IHSG salah satunya karena pasar menyambut positif pembukaan kembali aktivitas perekonomian pasca PSBB. 
5. Posisi IHSG sepanjang bulan Juli-Agustus 2020 cenderung bergerak di zona hijau. IHSG berada di level 5.149,63 pada Juli 2020 naik sebesar 244,44 poin dari bulan sebelumnya. Selanjutnya pada Agustus 2020 IHSG menguat di level 5.238,39. Penguatan IHSG terdorong apreasiasi pelaku pasar terhadap tingkat penyembuhan pasien positif corona berada diatas $50 \%$, hal ini dapat mengurangi kekhwatiran investor tentang virus corona.

6. Pada September 2020, IHSG mengalami tekanan namun tidak separah bulan Maret 2020. Penurupan perdagangan IHSG berada di level 4.870,04 dengan penurunan sebesar 368,45 poin dari bulan sebelumnya. Kondisi ini terjadi karena Gubernur DKI Jakarta menarik rem darurat dan menyatakan akan menerapkan PSBB sehubungan melonjaknya kasus Covid-19 di ibu kota. Sejumlah restoran, pusat perbelanjaan dan tempat hiburan mulai dibatasi aktivitasnya kembali. Hal ini membuat pelaku pasar menunggu dan melihat penerapan PSBB jilid kedua. Pelaku pasar menyimpan kekhwatiran terjadinya lonjakan kasus Covid-19 di dalam negeri.

7. Sepanjang Oktober 2020, kinerja IHSG cenderung bergerak di zona hijau yang di tutup di 5.128,23 dengan kenaikan sebesar 258,19 poin. Kenaikan IHSG ini salah satunya dipicu adanya pelonggaran status PSBB menjadi PSBB transisi. Pelaku pasar sedang merespon positif tentang pengajuan izin vaksin Covid-19 sehingga optimisme vaksin akan segera ditemukan dan segera distribusikan.

8. Kinerja IHSG bulan November 2020 mengalami penguatan sebesar 484,19 poin yang di tutup pada level 5.612,42. Penguatan IHSG ini terus berlanjut pada Desember 2020 yang menunjukkan kenaikan sebesar 366,65 poin yang di tutup pada posisi 5.979,07. Membaiknya kinerja IHSG di pasar keuangan salah satunya dipengaruhi vaksin Covid-19 yang akan tersedia tahun 2021. Pelaku pasar saham sangat optimis bahwa kehadiran vaksin Covid-19 di Indonesia akan dapat memulikan ekonomi menjadi normal kembali.

9. Pergerakan IHSG selama Januari 2021 mengalami penurunan sebesar 116,72 poin dari periode sebelumnya dan di tutup pada posisi 5,862.35. Pelemahan ini diprediksi karena pelaku pasar sedang mencermati kebijakan pemerintah dalam memperpanjang penerapan pembatasan kegiatan masyarakat (PPKM) di beberapa kota besar di Indonesia. Kebijakan PPKM dinilai dapat mendorong melambatnya daya beli masyarakat. Pelaku pasar juga sedang mengamati program vaksinasi oleh pemerintah terhadap pemulihan ekonomi.

10. Kinerja IHSG sepanjang Februari 2021 mengalami kenaikan yang signifikan sebesar 379,45 poin dari periode Januari 2021 yang di tutup pada level 6.241.80. Kinerja indeks sepanjang Februari 2021 cukup baik karena adanya apresiasi pelaku pasar terhadap vaksinasi massal yang berjalan baik di Indonesia. Optimisme pasar saham terhadap pemulihan ekonomi akan segera terwujud. 


\section{Kesimpulan dan Saran}

\subsection{Kesimpulan}

Berdasarkan hasil penelitian dan pembahasan yang dilakukan maka kesimpulan yang dari hasil penelitian ini adalah sebagai berikut :

1. Pada awal pandemi Covid-19 masuk ke Indonesia seluruh indeks sektoral di Bursa Efek Indonesia melemah dan berada di zona merah. Dari 10 indeks sektoral di BEI menunjukkan dampak yang berbeda saat melewati masa pandemi Covid-19 dalam 12 bulan perdagangan. Terdapat 8 sektor di BEI kurang terdampak dan 2 sektor sangat terdampak oleh pandemi Covid-19.

2. Terdapat 2 sektor di Bursa Efek Indonesia yang pergerakan sahamnya sedang naik atau tahan banting saat menghadapi pandemi Covid-19 yaitu Sektor Pertanian dan Sektor Perdagangan dan Jasa.

3. Sebanyak 6 sektor di Bursa Efek Indonesia yang pergerakan sahamnya stabil atau kurang terdampak saat menghadapi pandemi Covid-19 yaitu Sektor Pertambangan, Sektor Industri Dasar, Sektor Aneka Industri, Sektor Infrastruktur, Sektor Keuangan dan Sektor Manufaktur.

4. Terdapat 2 sektor di Bursa Efek Indonesia yang pergerakan sahamnya sedang turun atau sangat terdampak saat menghadapi pandemi Covid-19 yaitu Sektor Barang Konsumsi dan Sektor Properti.

5. Laju Indeks Harga Saham Gabungan berfluktuasi saat menghadapi pandemi Covid-19. Pada Maret 2020, laju IHSG mengalami penurunan dan masuk zona merah. Dari bulan April-Agustus 2020 laju IHSG mulai menguat secara perlahan dan berada di zona hijau. Pada perdagangan September 2020, laju IHSG kembali anjlok karena penerapan kebijakan PSBB fase ke dua. Dari Oktober 2020-Februari 2021, laju IHSG terus menguat dan perkasa pada Februari 2021.

\subsection{Saran}

Setelah melihat dampak yang ditimbulkan oleh pandemi Covid-19 terhadap kondisi pasar modal Indonesia maka disarankan kepada :

1. Pemerintah

Program vaksinasi nasional menjadi sentimen positif bagi pasar saham Indonesia oleh karena itu pemerintah disarankan segera menuntaskan sejumlah kendala dalam pelaksanaan vaksinasi Covid-19.

2. Pelaku Pasar Domestik

Untuk menjaga pergerakan laju IHSG di pasar modal maka pelaku pasar domestik dihimbau untuk tidak perlu reaktif dan panik berlebihan dalam menghadapi pandemi Covid-19 namun investor harus tetap waspada melihat perkembangan penyebaran Covid-19 apakah meluas atau tidak.

3. Masyarakat

Bagi masyarakat Indonesia dihimbau tetap menjalankan protokol kesehatan seperti memakai masker, mencuci tangan dan menjaga jarak fisik meskipun sudah divaksin supaya Indonesia dapat segera kembali untuk memulai hidup normal. 


\section{Referensi}

Bappennas: Daya Beli Masyarakat Merosot Rp 374,4 Triliun Akibat Pandemi Covid-19 (www.money.compas.com tanggal 28/12/2020)

Bursa Efek Indonesia 2020

Dampak Pandemi ke Properti, REI: Bisa Dibilang Kita Hadapi Masa Paling Kelam (www.bisnis.tempo.com tanggal 10/01/2021

IHSG Pekan Keempat Maret 2020 Melonjak, Reksadana Melesat (www.bareksa.com tanggal 30/03/2020).

Perjalanan IHSG Sejak RI Positif Virus Corona (www.finance.detik.com tanggal 10/04/2020).

Rekomendasi Saham dan Pergerakan IHSG (www.market.bisnis.com tanggal 23 Maret 2020)

Ritel Mau Bertahan Dari Badai Pandemi? (www.finance.detik.com tanggal 25/10/2020)

Sempat Menguat, IHSG Ditutup Melemah Dipicu Aksi Ambil Untung (www.bisnis.tempo.co tangga 24/03/2020).

Sertor Pertanian Tumbuh Dimasa Pandemi, Dinilai Sumbang Pertumbuhan Ekonomi (www.nasional.kompas.com tanggal 18/11/2020)

WHO Umumkan Wabah Dunia (www.kompas.com tanggal 12/03/2020). 